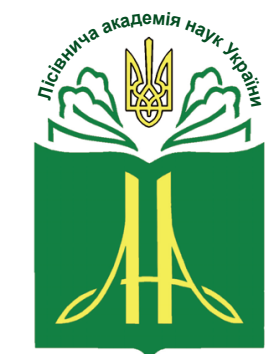

Forestry Academy of Sciences of Ukraine

Наукові праці Лісівничої академії наук України Proceedings of the Forestry Academy of Sciences of Ukraine

http://fasu.nltu.edu.ua https://doi.org/10.15421/412034

Article received 2020.04.19

Article accepted 2020.12.28
ISSN 1991-606X print

ISSN 2616-5015 online

@ $₫$ Correspondence author Vasyl Mazepa

vasyl.mazepa@gmail.com

General Chuprynka str., 103, Lviv, 79057, Ukraine

УДК 639.111.11

\title{
Вплив ратичних на рослинність у вольєрах Західного Полісся України
}

\author{
В.Г. Мазепа', П.Б. Хоєцький², А.М. Яцина
}

Наведено результати дослідження впливу ратичних на рослинність у різних за площею вольєрах Волинського обласного управління лісового та мисливського господарства. Облікові ділянки закладені у насадженнях, які до створення вольєрів та влаштування підгодівельних майданчиків належали до одного таксаційного виділу, щзо зумовлює їхню лісівничо-таксаційну подібність і дає змогу застосувати метод порівняльної екології.

Вплив ратичних на лісову рослинність вивчали у вольєрах і лісостанах Губинського, Карасинського та Муравищанського лісництв, щчо входять до структури державних підприємств «Володимир-Волинське ЛМГ», «Маневиџьке ЛГ» та «Ківериівське ЛГ» відповідно. У дубових деревостанах Губинського лісництва, де облаштовано вольєр з розведення Sus scrofa, щзо функиіонує з 2010 р., зареєстровано зменшення у два рази видового складу судинних рослин. У межах вольєру кількість життєздатного самосіву i niдpocmy Populus tremиla L. зменшилась у два, Ulmus scabra Mill. - у вісім, а Sambucus nigra L. - більш ніж у два рази.

У вольєрі Карасинського лісництва для розведення Sus scrofa, щзо функиіонував впродовж 2004-2010 рр., станом на 2017 р. зареєстровано відновлення трав'яного вкриття. Коефіцієнт подібності трав у березовососновому деревостані вольєру та за його межами становить 61,5\%.

У межсах вольєра, де утримують Bison bonasus, Cervus elaphus, Sus scrofa, зонами інтенсивного впливу ратичних на рослинність є підгодівельні майданчики. На функиіонуючих майданчиках не виявлено самосіву, підросту та підліску. Разом із кормами, якими підгодовують тварин, у лісове середовище потрапляє насіння сільськогосподарських культур і бур 'янів. Встановлено, щз з припиненням використання підгодівельних майданчиків, з трав'яного вкриття випадають зернові сільськогосподарські рослини та бур'яни і відновлюється лісова рослинність.

Ключові слова: трав'яне вкриття; підріст; підлісок; підгодівельний майданчик; Sus scrofa; Bison bonasus; Cervus elaphus.

Вступ. Рентабельне ведення мисливського господарства полягає у невиснажливому і раціональному використанні мисливських ресурсів на засадах наближеного до природи господарювання (Хоєцький, 2011). Однак, в Україні внаслідок порушення структури популяцій основних видів мис- ливських тварин, інтенсивної господарської діяльності, що призвела до погіршення умов існування дичини, порушення правил полювання (браконьєрство), недостатньої кількості фахівців, чисельність мисливських звірівіптахів єнезначною. Мисливські угіддя України потенційно багатші за угіддя євро-

Мазепа Василь Григорович - академік Лісівничої академії наук України, доктор сільськогосподарських наук, професор кафедри лісівництва. Національний лісотехнічний університет України, вул. Генерала Чупринки, 103, м. Львів, 79057, Україна. Тел.: +38-097788-45-10. E-mail: vasyl.mazepa@gmail.com ORCID: https://orcid.org/0000-0003-2149-3409

2 Хоєцький Павло Богданович - член-кореспондент Лісівничої академії наук України, доктор сільськогосподарських наук, професор кафедри лісівництва. Національний лісотехнічний університет України, вул. Генерала Чупринки, 103, м. Львів, 79057, Україна. Тел.: +38-068-845-84-77. E-mail:hpb@ua.fm ORCID: https://orcid.org/0000-0001-9726-953X

3 Яцина Андрій Мар 'янович - директор ДП «Поліське ЛГ». Державне підприємство «Поліське лісове господарство», вул. Комарова, 38, смт. Маневичі, 44600, Україна. Тел.: +38-067-361-80-07. E-mail:poliske@lisvolyn.gov.ua 
пейських країн, але ефективність мисливського господарства в країні значно поступається такій у Європі. У країнах Західної Свропи поголів'я ратичних характеризується істотною чисельністю та щільністю (Хоєцький, Похалюк, 2014). Зокрема, у Словаччині, щороку добувають понад 90 тис. голів ратичних, в Австрії - 300-400 тис. особин, що становить 58 голів на 1000 га мисливських угідь (Делеган, Делеган, 2014; Лущак, Делеган, Гунчак, 2007).

В Україні чисельність ратичних незначна. У 2017 р. в мисливських угіддях країни обліковано понад 215 тис. голів. Зокрема, чисельність оленя лісового становила понад 12,5 тис. особин, добування - близько 300 голів. Незначна чисельність поголів'я ратичних в Україні та, зокрема, в угіддях Західного Полісся (понад 28 тис. голів), зумовлює необхідність запровадження заходів, спрямованих на збільшення популяцій мисливських видів. Одним із шляхів підвищення ефективності ведення мисливського господарства, збільшення чисельності мисливських звірів і птахів, є розведення диких тварин у вольєрних умовах (Forejtek, 1999; Zbanek, 2000; Pintír, 2000, 2000a; Лисенко, 2008; Похалюк, 2016; Похалюк, 2017; Бугрин, Партика, Похалюк, 2018; Мазепа, Колісник, Хоєцький, 2019).

Станом на початок 2017 р. поголів'я ратичних на загороджених територіях в Україні становило понад 2,7 тис. особин. Вихід молодняка оленеподібних у розплідниках і фермах становив близько 1,2 тис. особин. Незначний приплід зумовлений відсутністю досвіду утримання ратичних у вольєpax. Умови утримання звірів у неволі повинні максимально сприяти реалізації репродуктивного по- тенціалу маточного поголів'я за обов'язкового забезпечення еколого-гігієнічного та протиепізоотичного захисту стада.

Життєдіяльність ратичних видів в умовах різних за площею загороджених територій призводить до зміни фізико-хімічних властивостей грунту і впливу на рослинність (Бондаренко, Білий, Ходзінський, 2007). Одним із недоліків вольєрного господарства $є$ зменшення біологічного різноманіття на загородженій території (Бахур, 2012). У великих за площею вольєрах особливої уваги потребують місця викладки кормів і концентрації звірів - підгодівельні майданчики. Тому, з лісівничого погляду, актуальним є питання дослідження впливу життєдіяльності ратичних тварин на рослинність у вольєрних умовах.

Об'скти та методика досліджень. Об' $\epsilon$ 'кm досліджень - рослинність у межах вольєрів в умовах Західного Полісся України. Предмет досліджень - вплив ратичних тварин на рослинність. Мета роботи - проаналізувати вплив ратичних на видовий склад трав'яного вкриття, природне поновлення та санітарний стан деревостанів у різних за площею вольєрах Волинського обласного управління лісового і мисливського господарства.

Дослідження здійснювали у вольєрах, розташованих в угіддях Губинського лісництва ДП «Володимир-Волинське ЛМГ», Карасинського лісництва ДП «Маневицьке ЛГ» і Муравищанського лісництва ДП «Ківерцівське ЛГ» впродовж літнього періоду 2017 року. Лісівничо-таксаційну характеристику насаджень, в яких закладені пробні площі, наведено в табл. 1.

Таблиияя 1

\section{Лісівничо-таксаційна характеристика деревостанів на пробних площах}

\begin{tabular}{|c|c|c|c|c|c|}
\hline Кв. & Вид. & $\begin{array}{c}\text { Склад } \\
\text { деревостану }\end{array}$ & $\begin{array}{l}\text { Індекс типу } \\
\text { лісу }\end{array}$ & $\begin{array}{c}\text { Вік } \\
\text { деревостану, років }\end{array}$ & Повнота \\
\hline \multicolumn{6}{|c|}{ Губинське лісництво } \\
\hline 30 & 13 & 3Дз2Дчр3Сз2Бр+Ялє & $\mathrm{C}_{2}$-гД & 28 & 0,70 \\
\hline \multicolumn{6}{|c|}{ Карасинське лісництво } \\
\hline 7 & 25 & 9Сз1Бп & $\mathrm{B}_{3}-д \mathrm{C}$ & 79 & 0,73 \\
\hline \multicolumn{6}{|c|}{ Муравищанське лісництво } \\
\hline 38 & 7 & 7Сз3Бп & $\mathrm{B}_{3}-д \mathrm{C}$ & 46 & 0,77 \\
\hline 39 & 1 & 9Сз1Бп & $\mathrm{B}_{3}-д \mathrm{C}$ & 53 & 0,77 \\
\hline
\end{tabular}

Пробні площі закладені у насадженнях, які до створення вольєру та влаштування підгодівельного майданчика належали до одного таксаційного виділу, що зумовлює їх лісівничо-таксаційну подібність і відповідає умовам застосування методу порівняльної екології (Погребняк, 1993). На пробних площадках здійснювали суцільний облік дерев за породами, ступенями товщини і категоріями санітарного стану. Оцінювання дерев за категоріями стану здійснювали за загальноприйнятою шкалою: здорові (I), ослаблені (II), сильно ослабле- ні (III), всихаючі (IV), свіжий сухостій (V), старий сухостій (VI) (Мазепа, Тереля, 2000).

У межах вольєру, підгодівельного майданчика, відповідно до загальноприйнятої методики (Воробьёв, 1967), закладали через однакову відстань 25 пробних площадок розмірами $2 \times 2$ м. Для порівняльного аналізу за межами вольєра, підгодівельного майданчика здійснювали облік рослинності на 25-ти контрольних площадках. На пробних площадках визначали кількість самосіву та підросту деревно-чагарникових порід, а також ви- 
довий склад, трапляння і проективне вкриття (\%) трав'яних рослин. Ступінь проективного вкриття встановлювали для кожного виду рослин за шкалою Г. М. Висоцького (Воробьёв, 1967). Уточнення назв видів рослин та їх визначення здійснювали за визначником вищих рослин України (Доброчаева и др., 1987). Подібність трав'яного вкриття у вольєрі, на підгодівельному майданчику та за їх межами розраховували за коефіцієнтом подібності Жаккара.

Результати досліджень. Вольєр у лісовому фонді Губинського лісництва (кв. 30, вид. 13, пл. 0,6 га) призначений для розведення дикої свині, який використовують 32010 року. У межах вольєру ідентифіковано шість видів трав, а за межами - 17 видів (табл. 2).

\section{Видовий склад, трапляння і рясність трав'яного вкриття на пробних площах}

(1, 3 - у межах вольєру, 2, 4 - за межами вольєру)

\begin{tabular}{|c|c|c|c|c|}
\hline \multirow{2}{*}{ Вид } & \multicolumn{2}{|c|}{ Губинське л-во } & \multicolumn{2}{|c|}{ Карасинське л-во } \\
\hline & 1 & 2 & 3 & 4 \\
\hline Aegopodium podagraria $\mathrm{L}$. & - & $96 / 5,5$ & - & - \\
\hline Pulmonaria officinalis L. & - & $88 / 4,6$ & - & - \\
\hline Asarum europaeum L. & - & $96 / 4,4$ & - & - \\
\hline Urtica dioica $\mathrm{L}$. & $40 / \mathrm{p}$ & $44 / n$ & - & - \\
\hline Athyrium filix-femina (L.) Roth & - & 4/un & - & - \\
\hline Carex sylvatica Huds. & - & $28 / \mathrm{n}$ & - & - \\
\hline Geum urbanum L. & - & $20 / \mathrm{n}$ & - & - \\
\hline Stellaria holostea L. & - & $48 / 5,0$ & - & - \\
\hline Galeopsis tetrahit L. & - & $64 / 1,7$ & - & - \\
\hline Impatiens noli-tangere L. & - & 8/un & - & - \\
\hline Polygonatum multiflorum (L.) All. & - & 20/un & - & - \\
\hline Paris quadrifolia $\mathrm{L}$. & - & $12 / \mathrm{n}$ & - & - \\
\hline Viola reichenbachiana Jordan ex Boreau & - & $32 / \mathrm{n}$ & - & - \\
\hline Pleurozium schreberi (Brid.) Mitt. & - & $40 / 1,3$ & $69 / 7$ & $31 / 8$ \\
\hline Mycelis muralis (L.) Dumort. & - & 4/un & - & - \\
\hline Achillea millefolium L. p. p. & - & 4/un & - & - \\
\hline Ajuga reptans $\mathrm{L}$. & $12 / \mathrm{n}$ & 4/un & - & - \\
\hline Cirsium avense (L.) Scop. & $8 / \mathrm{n}$ & - & - & - \\
\hline Hypericum perforatum $\mathrm{L}$. & $20 / \mathrm{n}$ & - & - & - \\
\hline Avena sativa $\mathrm{L}$. & $32 / \mathrm{n}$ & - & - & - \\
\hline Oxalis acetosella $\mathrm{L}$. & $4 / \mathrm{n}$ & - & - & - \\
\hline Calamagrostis epigeios (L.) Roth. & - & - & $85 / 11$ & $39 / 4$ \\
\hline Vaccinium myrtillus $\mathrm{L}$. & - & - & $100 / 23$ & $54 / 11$ \\
\hline Pteridium aquilinum (L.) Kuhn & - & - & $69 / p$ & $15 /$ un \\
\hline Vaccinium vitis-ideaea $\mathrm{L}$. & - & - & $92 / 1$ & $62 / 1,2$ \\
\hline Oxycoccus palustris Pers. & - & - & - & 8/un \\
\hline Ledum palustre $\mathrm{L}$. & - & - & $23 / 2,2$ & $23 / 1,7$ \\
\hline Carex brizoides $\mathrm{L}$. & - & - & $15 /$ un & 8/un \\
\hline Robus caesius L. & - & - & - & 8/un \\
\hline Sphagnum palustre L. & - & - & - & $23 / 4$ \\
\hline Melampyrum pretense $\mathrm{L}$. & - & - & $15 / \mathrm{n}$ & $15 /$ un \\
\hline Carex pilosa Scop. & - & - & - & $15 /$ un \\
\hline Calluna vulgaris (L.) Hull. & - & - & $31 / \mathrm{p}$ & - \\
\hline
\end{tabular}

Примітка: чисельник - трапляння видів рослин (\%), знаменник - рясність трав'яного вкриття (проективне вкриття у \%), р - розкидані екземпляри у незначній кількості, $\mathrm{n}$ - поодинокі екземпляри, un - один-два екземпляри на пробних площадках 
У вольєрі у незначній кількості зареєстрована Urtica dioica, траплялися поодинокі екземпляри п'яти видів рослин (Hypericum perforatum, Avena sativa, Cirsium avense, Ajuga reptans, Oxalis acetosella). Окремі 3 них (Cirsium avense, Avena sativa) потрапили на огороджену територію 3 кормами, якими здійснювали підгодівлю дикої свині. Істотне зменшення видів (майже у три рази) спричинене незначною площею вольєру $(0,6$ га) і тривалим використанням (протягом семи років) огородженої території. За межами вольєру найчастіше траплялися Aegopodium podagraria, Asarum europaeum, Pulmonaria officinalis, Galeopsis tetrahit та Stellaria holostea. Спільними видами, які поширені у вольєрі та контрольній площі, є Urtica dioica i Ajuga reptans. Індекс подібності між трав'яним вкриттям у вольєрі та за межами огородженої території незначний і становить 9,5\%.

Вольєр у Карасинському лісництві (кв. 7, вид. 25 , пл. 3,0 га) організований у 2004 р. для розведення диких свиней і функціонував до 2010 року.
У вольєрі виявлено дев'ять видів трав, за його межами - 12 видів. В умовах вольєру домінуючими видами є Vaccinium myrtillus, Vaccinium vitisideaea, Calamagrostis epigeios, Pteridium aquilinum i Pleurozium schreberi. За проективним вкриттям переважають Vaccinium myrtillus, Calamagrostis epigeios i Pleurozium schreberi, їх загальна рясність становить $41 \%$. За межами вольєра найчастіше трапляються Vaccinium vitis-ideaea, Vaccinium myrtillus, Calamagrostis epigeios i Pleurozium schreberi, а найбільше проективне вкриття зафіксовано у Vaccinium myrtillus, Pleurozium schreberi, Sphagnum palustre та Calamagrostis epigeios. Рясність їх становить 27\%, а коефіцієнт подібності трав'яного вкриття - 61,5\%.

У Муравищанському лісництві з 2010 р. функціонує вольєр площею 208 га. Тут утримують зубра, оленя лісового, дику свиню. У межах вольєра зонами інтенсивного впливу ратичних $є$ підгодівельні майданчики. На підгодівельному майданчику (пробна площа № 5) зареєстровано сім видів трав, а за його межами (пробна площа № 6) - вісім (табл. 3).

Видовий склад, трапляння і рясність трав'яного вкриття на пробних площах

Табличя 3 Муравищанського лісництва

\begin{tabular}{|c|c|c|c|c|}
\hline \multirow{2}{*}{ Види рослин } & \multicolumn{4}{|c|}{ № пробної площі } \\
\hline & 5 & 6 & 7 & 8 \\
\hline 1 & 2 & 3 & 4 & 5 \\
\hline Vaccinium myrtillus $\mathrm{L}$. & $24 / \mathrm{p}$ & $100 / 38$ & $48 / 8$ & $100 / 44$ \\
\hline Calamagrostis epigeios (L.) Roth. & $24 / 1$ & $100 / 19$ & $16 / \mathrm{p}$ & $100 / 19$ \\
\hline Avena sativa $\mathrm{L}$. & $72 / 7$ & - & - & - \\
\hline Calysteria sepium $\mathrm{L}$. & 8/un & - & $48 / \mathrm{p}$ & - \\
\hline Chenopodium album $\mathrm{L}$. & $20 / \mathrm{p}$ & - & $12 / \mathrm{un}$ & - \\
\hline Galium aparine $\mathrm{L}$. & 4/un & - & $20 / \mathrm{n}$ & - \\
\hline Oxalis acetosella $\mathrm{L}$. & 4/un & - & $16 / \mathrm{n}$ & - \\
\hline Trientalis europaea $\mathrm{L}$. & - & 8/un & 4/un & 8/un \\
\hline Vaccinium vitis-ideaea $\mathrm{L}$. & - & $56 / \mathrm{p}$ & $28 / \mathrm{p}$ & $56 / \mathrm{p}$ \\
\hline Hylocomium splendens (Hedm.) Schimp. & - & $92 / 45$ & $40 / 12$ & $96 / 41$ \\
\hline Rubus saxatilis L. & - & $8 / \mathrm{n}$ & $12 / \mathrm{n}$ & $12 / \mathrm{n}$ \\
\hline Majanthemum bifolium (L.) F. W. Smidt & - & 4/un & - & 4/un \\
\hline Melampyrum pratense L. & - & $8 / \mathrm{n}$ & $12 / \mathrm{n}$ & $12 / \mathrm{n}$ \\
\hline Festuca ovina L. & - & - & $72 / 4$ & - \\
\hline Rumex acetosa $\mathrm{L}$. & - & - & $12 / \mathrm{n}$ & - \\
\hline Hieracium pilosella $\mathrm{L}$. & - & - & $52 / \mathrm{p}$ & - \\
\hline Stellaria media $\mathrm{L}$. & - & - & $28 / \mathrm{p}$ & - \\
\hline Veronica officinalis L. & - & - & 4/un & - \\
\hline Urtica dioica $\mathrm{L}$. & - & - & $8 / \mathrm{n}$ & - \\
\hline Plantago major $\mathrm{L}$. & - & - & 4/un & - \\
\hline Artemisia absinthium L. & - & - & 4/un & - \\
\hline Euphorbia cyparissias L. & - & - & 4/un & - \\
\hline Capsella bursa-pastoris L. & - & - & 8/un & - \\
\hline
\end{tabular}




\begin{tabular}{lcccc} 
& & & Продовж. табл. 3 \\
\hline \multicolumn{1}{c}{1} & 2 & 3 & 4 & 5 \\
\hline Taraxacum officinale Wigg. aggr. & - & - & $4 / \mathrm{n}$ & - \\
Achillea millefolium L. p. p. & - & - & $4 / \mathrm{un}$ & - \\
Potentilla argentea L. & - & - & $4 / \mathrm{un}$ & - \\
Vaccinium uliginosum L. & - & - & - & $8 / \mathrm{un}$ \\
Athyrium filix-femina (L.) Roth & - & - & $12 / \mathrm{n}$ \\
Sphagnum palustre L. & - & - & $8 / 2$ \\
Calluna vulgaris (L.) Hull. & - & - & $4 / \mathrm{un}$ \\
Polytrichum commune Hedw. & - & - & $8 / \mathrm{n}$ \\
\hline
\end{tabular}

Примітка: чисельник - трапляння видів рослин (у \%); знаменник - рясність трав'яного вкриття (проективне вкриття у \%), р - розкидані екземпляри у невеликій кількості, n- поодинокі екземпляри, un - один-два екземпляри на пробну площадку

Проективне вкриття Avena sativa становить 7\%, інші рослини, за винятком Calamagrostis epigeios (1\%), трапляються поодинокими екземплярами. Також виявлено відмінність у видовому складі трав'яного вкриття. П'ять видів, які зареєстровані на підгодівельному майданчику, відсутні за його межами. 3 них, один вид культурної рослини (Avena sativa) та два види бур'янів (Calysteria sepium, Chenopodium album).

За межами підгодівельного майданчика у березово-сосновому деревостані найчастіше трапляються Vaccinium myrtillus, Calamagrostis epigeios, а також Hylocomium splendens та Vaccinium vitisideaea. У трав'яному вкритті у межах виділу характерне переважання Hylocomium splendens (проективне вкриття 45\%), Vaccinium myrtillus (38\%) i менше - Calamagrostis epigeios (19\%). Коефіцієнт подібності незначний і становить 15,4\%.

Істотною видовою різноманітністю трав характеризується другий підгодівельний майданчик (пробна площа №7), на якому припинили підгодівлю тварин у 2014 році. Тут зареєстровано 25 видів трав. Найчастіше трапляються Festuca ovina, Hieracium pilosella, Vaccinium myrtillus та Calysteria sepium. У проективному вкритті переважають Hylocomium splendens (12\%) i Vaccinium myrtillus (8\%). Коефіціент подібності трав'яного вкриття становить 26,7\%. На підгодівельному майданчику відсутній Avena sativa, але продовжують проростати, як і на першому підгодівельному майданчику, бур'яни (Calysteria sepium, Chenopodium album).

Майже вдвічі менше видів виявлено у трав'яному вкритті за межами підгодівельного майданчика (пробна площа № 8). Найчастіше трапляються Vaccinium myrtillus, Calamagrostis epigeios, Hylocomium splendens, менше - Vaccinium vitisideaea. Однак, проективне вкриття деяких видів (Vaccinium myrtillus, Hylocomium splendens) за межами підгодівельного майданчика у 3-4 рази більше, ніж на майданчику. На підгодівельному майданчику близько 40\% трав відносяться до лучних і бур'янів, не характерних для лісового середовища. Видовий склад трав на пробній площі № 8 характеризується подібністю до трав’яного вкриття на пробній площі № 6, коефіцієнт подібності становить $61,5 \%$.

У вольєрі Губинського лісництва кількість видів підросту і підліску сосново-дубового насадження $є$ меншою, ніж за його межами (табл. 4).

Зокрема, на огородженій території виявлено підріст Populus tremula, Ulmus scabra та Sambucus nigra, а за їі межами - сім видів деревних і чотири види чагарникових рослин. За межами вольєра виявлено життєздатного самосіву і підросту Populus tremula у два рази, Ulmus scabra - у вісім разів, а Sambucus nigra - понад два рази більше, ніж у межах вольєра.

На огородженій території зареєстровано 13 деревних видів, а за межами - дев'ять. Категорія стану деяких видів (Pinus sylvestris, Picea abies) не змінилася, але їхня частка у складі деревостану незначна. У Carpinus betulus санітарний стан змінився від здорового (за межами вольєра) до сильно ослабленого (у вольєрі). Зареєстрована зміна категорії стану в інших видів: Salix caprea (з 1,3 до 2,5), Betula pendula (з 1,2 до 2,2), Populus tremula (3 1,5 до 2,3), Quercus robur (з 2,0 до 2,7).

Виявлено також відмінність деревних видів за сортиментами. Зокрема, у Prunus avium напівділових сортиментів у вольєрі не виявлено (лише дров' яні), а за межами напівділові сортименти становили 14,3\% (дров'яні - 85,7\%). Відсутні ділові copтименти у Pinus sylvestris, а частка напівділової деревини зменшилася майже утричі: 3 48\% (за межами вольєра) до 17\% (у вольєрі).

В угіддях Карасинського лісництва, через припинення використання вольєра, відмінність у видовому складі деревно-чагарникової рослинності виражена слабше. На території вольєра зареєстровано підріст трьох деревних видів (Quercus robur, Sorbus aucuparia, Populus tremula), а за його межами - шість (Pinus sylvestris, Quercus robur, Betula pendula, Sorbus aucuparia, Populus tremula, Salix caprea). На огородженій території та за їі межами в підліску траплялася лише Frangula alnus. На функціонуючому підгодівельному майданчику Муравищанського лісництва (пробна площа № 5) не виявлено підросту, а за його межами - наявний підріст 
чотирьох деревних видів (Pinus sylvestris, Quercus robur, Betula pendula, Sorbus aucuparia). На майданчику, де підгодівлю припинили (пробна площа № 7), видовий склад підросту і підліску подібний до тако- го на контрольній ділянці (пробна площа № 8). Характерною особливістю була наявність підстилки на всіх пробних площах, де вона у 3-5 разів товща $(6,5-$ 7,8 см), ніж на підгодівельних майданчиках.

\section{Кількість життсздатного самосіву та підросту деревно-чагарникових порід під наметом деревостанів на пробних площах (чисельник - трапляння, \%; знаменник - чисельність, тис. шт.•га ${ }^{-1}$ )}

\begin{tabular}{|c|c|c|c|c|c|c|c|c|}
\hline \multirow{3}{*}{ Види рослин } & \multicolumn{8}{|c|}{ Лісництво, номер пробної площі } \\
\hline & \multicolumn{2}{|c|}{ Губинське } & \multicolumn{2}{|c|}{ Карасинське } & \multicolumn{4}{|c|}{ Муравищанське } \\
\hline & 1 & 2 & 3 & 4 & 5 & 6 & 7 & 8 \\
\hline Pinus sylvestris L. & - & - & & $16 / 0,8$ & - & $8 / 0,4$ & $16 / 1,2$ & $68 / 1,0$ \\
\hline Quercus robur L. & - & - & $8 / 0,4$ & $8 / 0,2$ & - & $16 / 0,4$ & $16 / 0,5$ & $4 / 0,1$ \\
\hline Betula pendula Roth. & - & - & - & $16 / 0,4$ & - & $4 / 0,1$ & $12 / 0,3$ & $4 / 0,1$ \\
\hline Sorbus aucuparia L. & - & - & $31 / 0,8$ & $17 / 0,4$ & - & $4 / 0,1$ & - & - \\
\hline Populus tremula $\mathrm{L}$. & $4 / 0,1$ & $8 / 0,2$ & $32 / 2,3$ & $16 / 0,6$ & & - & - & - \\
\hline Salix caprea L. & - & - & - & $17 / 0,8$ & & - & - & - \\
\hline Ulmus scabra Mill. & $8 / 0,2$ & $48 / 1,6$ & - & - & & & - & - \\
\hline Acer pseudoplatanus $\mathrm{L}$. & - & $4 / 0,2$ & - & - & - & & - & - \\
\hline Acer platanoides L. & - & $4 / 0,2$ & - & - & - & - & - & - \\
\hline Picea abies (L.) Karsten & - & $4 / 0,1$ & - & - & - & - & - & - \\
\hline Tilia cordata Mill. & - & $4 / 0,1$ & - & - & - & - & - & - \\
\hline Carpinus betulus L. & - & $4 / 0,1$ & - & - & - & - & - & - \\
\hline Corylus avellana $\mathrm{L}$. & - & $8 / 0,4$ & - & - & - & - & - & - \\
\hline Euonymus europaea L. & - & $4 / 0,1$ & - & - & - & - & - & - \\
\hline Frangula alnus Mill. & - & - & $62 / 3,4$ & $25 / 3,1$ & - & $72 / 3,4$ & $24 / 0,9$ & $61 / 3,0$ \\
\hline Sambucus nigra $\mathrm{L}$. & $36 / 1,3$ & $52 / 3,1$ & - & - & - & - & - & - \\
\hline Swida sanquinea (L.) Opiz. & - & $32 / 1,4$ & - & - & - & - & - & - \\
\hline $\begin{array}{l}\text { Трапляння (\%) і товщина } \\
\text { лісової підстилки (см) }\end{array}$ & - & - & - & - & $36 / 2,0$ & $100 / 6,5$ & $60 / 1,4$ & $100 / 7,8$ \\
\hline
\end{tabular}

Примітка: пробні площі: 1, 3 - у вольєрі, 2, 4 - за межами вольєра; 5, 7 - підгодівельний майданчик, 6, 8 - за межами підгодівельного майданчика

На підгодівельному майданчику (пробна площа № 7) зареєстровано три види деревних рослин (Pinus sylvestris, Betula pendula, Quercus robur), а за межами - лише два (Pinus sylvestris, Betula pendula). Категорії стану деревних видів практично не зазнали змін. Так, у Pinus sylvestris на підгодівельному майданчику категорія стану становила 2,4, а за межами - 2,3, у Betula pendula - на підгодівельному майданчику - 4,3, за межами - 4,2.

Висновки. У незначних за площею вольєрах $\mathrm{i}$ тривалому утриманні мисливських ратичних тварин видовий склад судинних тут зменшується у 2,8 рази порівняно із незагородженими територіями. У межах вольєра трави трапляються у незначній кількості. Коефіцієнт подібності між трав'яним вкриттям у вольєрі з розведення Sus scrofa, що функціонує з 2010 р., і контрольній площі незначний і становить 9,5\%. Кількість видів у підрості і підліску у дубових деревостанах на огородженій території менша, ніж за їі межами. У межах вольєра кількість життєздатного самосіву і підросту Populus tremula зменшилась у два рази, Ulmus scabra - у вісім разів, a Sambucus nigra - більш ніж у два рази порівняно із незагородженими територіями.

На огородженій території зареєстровано незначну зміну категорії санітарного стану низки деревних видів - Salix caprea, Betula pendula, Populus tremula, Quercus robur. Внаслідок впливу дикої свині, у межах вольєра санітарний стан дерев Carpinus betulus змінився до сильно ослабленого порівняно із здоровим станом за межами вольєру.

У вольєрах, які вилучені із користування, природне трав'яне вкриття відновлюється через 4-6 років. Коефіцієнт подібності трав на огородженій території та за іiі межами становить $61,5 \%$. У березово-соснових деревостанах у межах діючо- 
го підгодівельного майданчика не виявлено самосіву, підросту та підліску. У складі рослинності на підгодівельному майданчику зареєстровано не характерні для лісостанів сільськогосподарські культури і бур'яни. Всього виявлено сім видів трав, у т.ч. культурну рослину (Avena sativa) та два види бур'янів (Calysteria sepium, Chenopodium album). 3 припиненням використання підгодівельного майданчика у трав'яному вкритті зникають сільськогосподарські рослини та бур'яни і відновлюється лісова рослинність.

\section{Список літератури}

Бахур, О.В. (2012). Опыт ведения вольерного лесоохотничьего хозяйства «Шерешовское». Труды Брянского гос. техн. ун-та, 1, 69-71 [Bakhur, O. V. (2012). The experience of the open-air cage forestry «Shereshovskoye». Proceedings of Bryansk State Technical University, 1, 69-71 (in Russian)]. Retrieved from https:// cyberleninka.ru/article/n/opyt-vedeniya-voliernogolesoohotnichiego-hozyaystva-shereshovskoe

Бондаренко, В.Д., Білий, В. В., Ходзінський, В.П. (2007). Зміна фізико-хімічних властивостей грунту під впливом риючої діяльності свині дикої. Науковий вісник Надслучанського інституту: Проблеми Західного Полісся, 1, 117-121 [Bondarenko, V.D., Biliy, V.V., \&Khodzinsky, V.P. (2007). A change of physical and chemical powers to the soil before the inundation of the wild pigs. Scientific Bulletin of the Nadsluchany Institute: Problems of Western Polissya, 1, 117-121 (in Ukrainian)]

Бугрин, Л. М., Партика, Т. В., Похалюк, О. М. (2018). Елементи технології створення пасовищ для оленя лісового в умовах вольєрного розведення. Науковий вісник НЛТУ Украӥни, 28 (2), 37-40 [Bugrin, L. M., Partika, T. V., \& Pohalyuk, O. M. (2018). Elements of technology for creating pastures for forest deer in aviary breeding. Scientific Bulletin of Ukrainian National Forestry University of Ukraine, 28 (2), 37-40 (in Ukrainian)]. https://doi.org/10.15421/40280205

Воробьёв, Д. В. (1967). Методика лесотипологических исследований. Киев: Урожай [Vorobiov, D.V. (1967). Methodology for forest typological research. Kyiv: Harvest (in Russian)]

Делеган, I.I., Делеган, I. В. (2014). Особливості організації ведення мисливського господарства у Словаччині. Науковий вісник НЛТУ Украӥни, 24.8, 52-57 [Delegan, I. I., \& Delegan, I. V. 2014). Features of the organization of hunting management in Slovakia. Scientific Bulletin of Ukrainian National Forestry University, 24.8, 52-57 (in Ukrainian)]. Retrieved from http:// nbuv.gov.ua/UJRN/nvnltu_2014_24.8_10

Доброчаева, Д.Н., Котов, М.И., Прокудин, Ю.Н., Барбарич, А.И., Чопик, В.И., Протопопова, В.В.... Орнст, Э.Й. (1987). Определитель высших растений Украины. Киев: Наукова думка [Dobrochaeva, D.N., Kotov, M.I., Prokudin, Yu.N., Barbarich, A.I., Chopik, V.I., Protopopova, V.V. ... Ornst, E.Y. (1987 ). Keys to higher plants of Ukraine. Kyiv: Scientific thought (in Russian)].
Лисенко, В.I. (2008). Перспективні шляхи нетрадиційного використання малоцінних сільськогосподарських угідь. Екологічний вісник, 3, 31-32 [Lysenko, V. I. (2008). Pathways for non-traditional use of low-value agricultural land. Ecological Bulletin, 3, 31-32 (in Ukrainian)]

Лущак, М., Делеган,I., Гунчак, М. (2007). 3 досвіду ведення мисливського господарства в Австрії. Лісове та мисливське господарство: сучасний стан $і$ перспективи розвитку: матеріали Міжнарод. наук.-практ. конф. (27-29.11.2007 p, м. Житомир), 2, 259-263 [Lushchak, M., Delegan, I., \& Gunchak, M. (2007). To the notice of the Mislivsky government in Austria. In Forestry and hunting: current status and prospects, 2, 259-263. Zhytomyr: Ukraine: PE «Publishing House Volyn» (in Ukrainian)]

Мазепа, В.Г., Колісник, Б.І., Хоєцький, П.Б. (2019). Трав'яне вкриття і запаси лучних кормів для утримання Cervus elaphus L. Наукові праці Лісівничої академї наук України, 19, 154-162 [Mazepa, V.G., Kolisnik, B.I., \& Khoetskyy, P.B. (2019). Herbs including archery food supplies for Cervus elaphus L. Proceedings of the Forestry Academy of Sciences of Ukraine, 19, 154-162 (in Ukrainian)]. https:// doi.org/10.15421/411937

Мазепа, В.Г., Тереля, І.П. (2000). Санітарний стан деревостанів та проект заходів щзодо його поліпшення: методичні вказівки. Львів: Укр. держ. лісотехн. ун-т [Mazepa, V.G., \& Terelya I.P. (2000). Sanitary camp of woodworkers and project of visits to the school. Lviv: Ukrainian State Forestry University (in Ukrainian)]

Погребняк, П. С. (1993). Лісова екологія і типологія лісів. Київ: Наукова думка [Pogrebnyak, P. S. (1993). Forest ecology and typology of forests.Kyiv: Scientific thought (in Ukrainian)]

Похалюк, О.М. (2017). Значення вольерного розведення диких тварин у збереженні рідкісних видів звірів. Тернопільські біологічні читання: матеріали наук.-практ. конф. (20-22 квітня 2017 р., Тернопіль), 227-341. [Pohalyuk, O.M. (2017). The value of free breeding of wild animals in the conservation of wild species of animals. In Ternopil biological reading, 227-341. Ternopil, Ukraine:Ternopil National Pedagogical University (in Ukrainian)]

Похалюк, О. М. (2016). Шляхи покращення ведення мисливського господарства в умовах Західного Полісся. Перспективи розвитку лісового та садово-паркового господарства: матеріали Всеукраїн. наук.-практ. конф. (14.12.2016 р., Умань), 166-167 [Pohalyuk, O.M. (2016). Ways to improve hunting management in the conditions of Western Polissya.In Prospects for the development of Forestry and Horticulture, 166-167. Uman, Ukraine: Uman National University of Horticulture (in Ukrainian)]

Хоєцький, П.Б. (2011). Концепція розвитку мисливського господарства Західного регіону України. Львів: НЛТУ України [Khoyetskyу, Р.В. (2011). The concept of development of the hunting 
economy of the Western region of Ukraine. Lviv: Ukrainian National Forestry University (in Ukrainian)]

Хоєцький, П. Б., Похалюк, О. М. (2014). Мисливське господарство країн Європи. Науковий вісник НЛТУ Украӥни, 24.8, 42-52 [Khoyetskyy, P.B., \& Pokhalyuk, O.M. (2014). Wildlife Management in European Countries. Scientific Bulletin of Ukrainian National Forestry University, 24.8, 42-52 (in Ukrainian)]. Retrieved from https://nv.nltu.edu.ua/Archive/2014/24_8/9.pdf

Forejtek, P. (1999). Chov cerne zvere na Slovensku. Myslivost. Straz myslivosti. Rocnik, 47 (6), 6-8 [Forejtek, P. (1999). Breeding black game in Slovakia. Myslivost. Straz myslivosti. Rocnik, 47 (6), 6-8 (in Czech)]

Pintír, J. (2000a). Intensivni chovy elenovitych v Ceske republice. Myslivost. Stráž myslivost. Rocnik 48 (1), 4-6 [Pintír, J. (2000a). Intensive breeding of cervids in the Czech Republic. Myslivost. Stráž myslivost. Rocnik 48 (1), 4-6 (in Czech)] Retrieved from https://www. myslivost.cz/Casopis-Myslivost/Myslivost/2000/ Leden---2000/Intenzivni-chovy-jelenovitych-vCeske-republice

Pintír, J. (2000). Metody chovu v intensivnich chovech jelenovitych. Myslivost. Strsz myslivosti. Rocnik, 48 (5), 14-15 [Pintír, J. (2000). Methods in intensive deer breeding Myslivost. Strsz myslivosti. Rocnik, 48 (5), 14-15 (in Czech)]. Retrieved from https://www.myslivost.cz/ Casopis-Myslivost/Myslivost/2000/Kveten---2000/ Metody-chovu-v-intenzivnich-chovech-jelenovitych Zbanek, S. (2000). Farmove chovy jelenovitych. Myslivost. Strsz myslivosti. Rocnik, 48 (9), 14-15 [Zbanek, S. (2000). Farm breeding of deer. Myslivost. Strsz myslivosti. Rocnik, 48 (9), 14-15 (in Czech)]. Retrieved from https://www.myslivost.cz/CasopisMyslivost/Myslivost/2000/Zari---2000/Farmovechovy-jelenovitych

\section{Impacts of hoofed animals on vegetation in aviaries of the Western Polissya of Ukraine}

\section{Mazepa', P. Khoyetskyy², A. Yatsyna ${ }^{3}$}

The study results of hoofed animals impact on vegetation in aviaries of different size of the Volyn Regional Department of Forestry and Hunting are

Vasyl Mazepa - full Member of the Forestry Academy of Sciences of Ukraine, doctor of agricultural Sciences, Professor, Professor of chair of Forestry. National forestry University of Ukraine, Generala Chuprynky str., 103, Lviv, 79057, Ukraine. Tel: +38-097-788-4510. E-mail: vasyl.mazepa@gmail.com ORCID: https://orcid. org/0000-0003-2149-3409

Pavlo Khoyetskyy - Corresponding Member of the Forestry Academy of Sciences of Ukraine, doctor of agricultural Sciences, Professor, Professor of chair of Forestry. National forestry University of Ukraine, Generala Chuprynky str., 103, Lviv, 79057, Ukraine. Tel: +38-068-845-84-77. E-mail: hpb@ua.fm ORCID: https://orcid.org/0000-0001-9726-953X

Andriy Yatsyna- Director of the State Enterprise «Polish Forestry», SE «Polish Forestry», Komarova str., 38, village Manevychi, Volyn region, 44600, Ukraine. Tel. +38-067-361-80-07. E-mail: poliske@, lisvolyn.gov.ua presented. The reaserch sites are laid in forest stand, which belonged (before the construction of the aviary and the arrangement of the feeding area) to one taxonomic department that determines their forestrytaxonomic identity what allows to apply the method of comparative ecology.

The impact of hunting hoofed animals on forest vegetation was studied in aviaries and forest stands of Gubynsky, Karasynsky and Muravyshchansky forestry units, which are part of the structure of state enterprises «Volodymyr-Volynske forestry», «Manevytsia forestry» and «Kivertsy forestry», respectively. In oak stands of the aviary of Gubinsky forestry for breeding Sus scrofa, which has been operating since 2010, as of 2017, a twofold decrease in the species composition of vascular plants was observed.

Outside the enclosure, 2 times more viable selfseeding and undergrowth of Populus tremula, Ulmus scabra - 8 times, and Sambucus nigra - more than 2 times were recorded. The coefficient of similarity between the grass cover inside and outside the enclosure is insignificant $-9.5 \%$. Within the enclosure, a slight change in the sanitary condition category of such tree species as Salix caprea, Betula pendula, Populus tremula, Quercus robur was registered. As a result of exposure of wild boar within the enclosure, the sanitary condition of Carpinus betulus trees has changed to significantly weakened compared to healthy outside the enclosure.

As of 2017, the grass cover restoration was registered in the aviary of Karasinsky forestry for breeding Sus scrofa, which operated from 2004 to 2010. In aviary conditions the dominant herbs are Vaccinium myrtillus, Vaccinium vitis-ideaea, Calamagrostis epigeios, Pteridium aquilinum and Pleurozium schreberi. The projective cover is dominated by Vaccinium myrtillus, Calamagrostis epigeios and Pleurozium schreberi, their total abundance is $41 \%$. The coefficient of similarity of grasses in the pine-birch stand of the aviary and outside it is $61.5 \%$.

Within the aviary of Muravyshchansky forestry, where Bison bonasus, Cervuselaphus, Sus scrofa are kept, the areas of intensive influence of hoofed animals on forest vegetation are feeding grounds. Self-seeding, undergrowth and undergrowth were not found in pine-birch stands within the existing feeding site. Crops and weeds that are not typical for forest stands have been found in the vegetation within the feeding site. A total of seven grass species were identified, including a cultivated plant (Avena sativa) and two weeds (Calysteria sepium, Chenopodium album).

Cultivated plants enter the forest environment together with the fodder they feed hoofed animals. It was found out that with the cessation of animal feeding, the composition of tree species and undergrowth species on the feeding site was restored and is identical to the vegetation outside it. Four years after the cessation of feeding of hunting animals, grain crops and weeds fall out of the grass cover of the former feeding ground and the forest environment 
is restored. There are 25 species of herbs registered here. The most common are Festuca ovina, Hieracium pilosella, Vaccinium myrtillus and Calysteria sepium. Hylocomium splendens (12\%) and Vaccinium myrtillus $(8 \%)$ predominate in the projective cover. Coefficient of similarity of the grass cover is $26.7 \%$. The sanitary condition of wood species on the functioning feeding site has not changed significantly.

Key words: grass cover; young growth; undergrowth; feeding ground; Sus scrofa; Bison bonasus; Cervus elaphus.

\section{Влияние копытных на растительность в вольерах Западного Полесья Украины}

\author{
В. Г. Мазепа', П.Б. Хоецкий ${ }^{2}$, А. М. Яцина
}

Приведены результаты исследования влияния копытных на видовой состав растительности в разных по площади вольерах Волынского областного управления лесного и охотничьего хозяйства. Учет-

Мазепа Василий Григорьевич - академик Лесной академии наук Украины, доктор сельскохозяйственных наук, профессор кафедры леоводства. Национальный лесотехнический университет Украины, ул. Генерала Чупринки, 103, г. Львов, 79057, Украина. Тел.: +38-097-788-45-10. E-mail: vasyl. mazepa@gmail.com ORCID: https://orcid.org/0000-0003-21493409

2 Хоеикий Павел Богданович - член-корреспондент Лесной академии наук Украины, доктор сельскохозяйственных наук, профессор кафедры лесоводства. Национальный лесотехнический университет Украины, ул. Генерала Чупринки, 103, г. Львов, 79057, Украина. Тел.: +38-068-845-84-77. E-mail: hpb@ua.fm ORCID: https://orcid.org/0000-0001-9726-953X

Яичина Андрей Марианович - директор ГП «Полесское ЛХ», государственное предприятие «Полесское лесное хозяйство», ул. Комарова, 38, пгт. Маневичи, Волинская обл., 44600, Украина. Тел.: +38-067-361-80-07. E-mail: poliske@lisvolyn.gov.ua ные участки заложены в насаждениях, которые до создания вольеров и устройства подкормочных площадок принадлежали к одному таксационному выделу, что предопределяет их лесоводственнотаксационную идентичность и позволяет применить метод сравнительной экологии.

Влияние копытных на лесную растительность изучали в вольерах и древостоях Губинского, Карасинского и Муравищанского лесничеств, входящих в структуру государственных предприятий «Владимир-Волынское лесоохотничье хозяйство», «Маневичское лесное хозяйство и «Киверцовское лесное хозяйство» соответственно. В дубовых древостоях Губинского л-ва, где обустроен вольер по разведению Sus scrofa, функционирующий с 2010 г., обнаружено уменьшение в два раза видового состава сосудистых растений. В пределах вольера количество жизнеспособного самосева и подроста Populus tremula L. уменьшилось в два раза, Ulmus scabra Mill. - в восемь раз, а Sambucus nigra L. - более чем в два раза.

В вольере Карасинского л-ва для разведения Sus scrofa, который функционировал на протяжении 2004-2010 гг., по состоянию на 2017 г. зарегистрировано восстановление травяного покрова. Коэффициент сходства трав в сосново-березовом древостое вольера и за ее пределами составляет $61,5 \%$.

В пределах вольера, где содержат Bison bonasus, Cervus elaphus, Sus scrofa, зонами интенсивного воздействия копытных на растительность являются подкормочные площадки. На функционирующей площадке отсутствует самосев, подрост и подлесок. Установлено, что с прекращением использования подкормочной площадки с травяного покрова исчезают зерновые сельскохозяйственные растения и сорняки, восстанавливается лесная растительность.

Ключевые слова: травяной покров; подрост; подлесок; подкормочная площадка; Sus scrofa; Bison bonasus; Cervus elaphus. 